\title{
Between the "Self" and the "Other": Representations of Ukraine's Russian-speakers in Social Media Discourse
}

\author{
Volodymyr Kulyk \\ (Institute of Political and Ethnic Studies, National Academy of Sciences of Ukraine)
}

\begin{abstract}
This paper analyzes the images of Ukraine's Russian-speaking citizens as they appear in Ukrainian users' posts on Facebook. Based on a systematic examination of the accounts of twelve prominent pro-Maidan personalities, my analysis pays attention to both the self-representations of those Ukrainians who primarily rely on the Russian language and to their representations by those individuals who locate themselves outside of this group. I argue that what usually appears in the self-representations as merely a facet of communicative practice is often perceived by others as a crucial element of social identity. While the selfrepresentations do not undermine Russian-speakers' identity as Ukrainians, the other-representations often do, thus questioning their belonging to the imagined national Self. Such opposing representations of Russian-speakers manifest different perceptions of the Ukrainian nation and the role of the Ukrainian language in this identity, and thus different ideologies of nationhood and language more generally.
\end{abstract}

Keywords: identity, discourse, social media, Facebook, Ukraine, Russian-speakers.

Cince social media have become one of the most influential types of discourse, they should come into focus of research dealing with the ideological processes taking place in discourse. The present article seeks to contribute to such a shift of focus by examining one of the most important of these processes, namely the construction of identities, which has been extensively studied in relation to various other discourses, including those of the "old," more traditional media. I analyze the images of Ukraine's Russian-speaking citizens as they appear in Ukrainian users' posts on Facebook. As one of the first works in Ukrainian studies to offer a systematic analysis of identity construction in social media discourse, this article illuminates the complexity of ethnolinguistic identities and language attitudes in Ukrainian society and demonstrates an important role of social media as a site of performing and discussing them.

In recent years, a popular uprising against an authoritarian regime and a subsequent foreign aggression highlighted Ukrainians' sense of nationhood and at the same time activated discussions about its meaning and consequences. One of the most controversial aspects turned out to be 
the relation between nation and language, particularly the role of the titular language, Ukrainian, in national identity and the acceptability of the former imperial language, Russian (Kulyk, "Ukrainian"; "Language and Identity"). While most speakers of both Ukrainian and Russian languages increasingly see themselves as Ukrainians, some question the national belonging of those who continue to rely on the Russian language in various social practices. This controversial issue quickly found its way into social media where it has become one of the most heatedly discussed topics, at least among politically active users. Such active appropriation of the new media for discussions of political and identity matters has been documented in various societies and transnational communities across the globe (Chan; KhosraviNik and Zia).

It is well established in the social sciences that identity construction is the interaction between one's assertion of a certain selfhood and the external ascription of certain characteristics to one's self (Brubaker and Cooper). Accordingly, my analysis of the images of Russian-speakers pays attention to both the self-representation of those Ukrainian users of Facebook who primarily rely on the Russian language and to their representation by other users who locate themselves outside of this group. Based on a systematic examination of posts by twelve prominent personalities, I argue that what usually appears in Russian-speakers' selfrepresentations as merely a facet of communicative practice is often perceived by others (those speaking Ukrainian and/or supporting its predominance in Ukrainian society) as a crucial element of social identity. And while the self-representations do not by any means undermine Russian-speakers' identity as Ukrainians, the other-representations often do, thus questioning their belonging to the imagined national Self. Such opposing representations of one group defined by its main everyday language manifest different perceptions of the Ukrainian nation and the role of the Ukrainian language in this identity, and thus different ideologies of nationhood and language more generally.

\section{IDENTITY, DISCOURSE, AND SOCIAL MEDIA}

In the social sciences, identity has traditionally been conceptualized as the way in which individuals define themselves by referring to certain prominent characteristics. The process of identification takes place in interaction with other people, whom an individual perceives as similar to or different from him- or herself, and whose perceptions of him- or herself such an individual may internalize to a certain extent. Moreover, the very categories in which one is likely to define oneself are molded by the prevalent system of knowledge in a given society, which posits particular 
importance of certain facets of human essence and the existence of certain collectivities (groups) distinguished by their typical ways of manifesting these facets. Individuals can thus identify, more or less strongly, with one of the groups defined by each supposedly important category (nation, gender, occupation, religion, etc.), and it is these individual identifications that (re)create or, more accurately, lend social meaning to the existence of the respective groups (Wodak et al.; Ibañez). No group is, however, fixed in the sense of who belongs to it or what the perceived belonging means, since each person identifies with many groups, permanently or situationally. The currently predominant constructivist approach sees identities as multiple, fluid, and contested, arguing that "people don't have an identity but that identities are constructed in practices that produce, enact, or perform identity-identity is identification, an outcome of socially conditioned semiotic work" (Blommaert 205; emphasis in the original).

This semiotic or, to use a more widespread term, discursive work includes both interpersonal interaction and the institutional inculcation (by no means uncontested) of appropriate ways of identification. In the nationally organized world, the state and other powerful institutions are particularly interested in people's identification as members of the respective nations (Anderson; Billig), while also contributing to their perceived belonging to various other groups. The media play a crucial role in this construction of identities in contemporary societies, if only because of the intensity of most people's participation in various types of media discourse. A number of studies have examined media contributions to the pre-eminence of national identity and media representations of various ethnocultural and sociodemographic groups (van Dijk; Morley; Gauntlett). The construction of identities has been of particular interest to scholars working within the paradigm of Critical Discourse Analysis, which conceptualizes this construction as one of the main ideological effects of discourse in general and media discourse in particular, even if these scholars did not always examine whether this effect has indeed been achieved (Fairclough; Wodak et al.; KhosraviNik).

The advent of the Internet and, later, social media led scholars to extend to the "new" media research tasks and methods they had been exploring in the "old" media and, at the same time, to shift their agenda toward issues reflecting particular features of the novel type of interaction. ${ }^{1}$ Many authors emphasized the inherent interactivity of

\footnotetext{
1 The term "social media" usually means "Internet-based applications that promote social interaction between participants," a class that includes not only social network sites such as Facebook but also discussion forums, blogs, wikis, microblogging, podcasting, and video sharing (Page 5). "User-generated content" is one of the defining characteristics of social media, which "means that today, anyone
} 
Internet communication, which arguably gives participants greater power than in the predominantly unidirectional print and broadcasting discourse, including the ability to construct their identities relatively free from external prescriptions. This new quality of interaction was recognized already in computer games in the first decade of the mass Internet where, Turkle argued, "the self is constructed and the rule of social interaction are built, not received" (10). While in computer games and chats online personae are more or less imaginary, social media primarily encourage interaction between "real" people (although many still prefer to not reveal who they are), which is meant to supplement or, in many cases, substitute for offline connections. In their profiles and status updates indicating certain background features and everyday activities, social media users construct their selves according to expectations that are prevalent in their respective offline and/or online groups and that evolve under the influence of technical features of the respective media (boyd and Heer; Siibak; Lee, "Micro-Blogging"). These self-representations bring them into digital "conversations" with other users which help sustain offline relations and, no less importantly, establish new, essentially online ones, thus making a communicating individual a member of one or many "virtual communities" (Smith and Kollock; Parks). One's performances in different communities present more or less dissimilar versions of one's self which often have to be reconciled, as social media such as Facebook and Twitter for most users serve multiple functions addressed at different audiences. Perhaps most obvious is the blurring between the private and public spheres and thus between personal and professional identities (Giplin; Page). A more particular example pertains to transnational migrants who "may simultaneously perform their cultural identities on Facebook to loved ones in the home country, new friends in the host country and members of their diasporic community around the world" (Aguila).

While most studies of the Internet and social media deal with mundane and non-political uses thereof, thus reflecting the distribution of online activities, ${ }^{2}$ a number of authors have examined the new media's role in deliberation on and mobilization around important political issues (Hill and Hughes; Kushin and Kitchener; Johnson et al.). Much attention has been paid to social media contributions to electoral campaigns and social protests (e.g., Bimber and Davis; Castells; Onuch), but scholars also recognized the importance of the more routine deliberation and persuasion. In the words of Holt: "The ability of the internet to unite those

with internet access can provide their opinions about any of their ... experiences" (Vásquez 65).

${ }^{2}$ A 2008 study found that 10 percent of all Americans who use social network sites use them "for some kind of political activity" (Kushin and Kitchener). 
of disparate backgrounds has great potential for fostering debate and discussion of issues in the civic arena" (14). Apart from posting their own verbal or audiovisual contributions and commenting on various texts that they come across, many users start or join groups or set up pages specifically intended for discussing certain topics. To be sure, most researchers (and users) quickly realized that "the Internet is by no means a fully democratic medium where the people come together to politely and rationally discuss viewpoints and arrive at the best possible conclusion" (Kushin and Kitchener). However, studies of online interaction have demonstrated that in political discussions, for example on Facebook, combative and abusive behavior known as flaming "does not dominate nor does it drive out those who seek to interact in a civil manner" (Kushin and Kitchener). Many such groups and pages are specifically devoted to discussing certain politically relevant identities whereby participants emphasize their common belonging to the respective collectivity but often disagree about the meaning of this belonging. As in other types of media discourse, the nation plays a special role among such collectivities, both as a framework for civic engagement within the respective state and as a spiritual unity of kindred people regardless of distances and borders (Chan; KhosraviNik and Zia; Kozachenko). Moreover, serious and often heated discussion of identity matters also takes place on personal pages in response to status updates that are either intended to initiate a discussion or unexpectedly trigger it despite the author's intention to report his or her seemingly mundane activities, feelings or thoughts (Lee, "Micro-Blogging"; Kulyk, "Negotiating").

Language is an important aspect of identity which can be discussed in specific groups or pages and performed in profiles or updates. Moreover, like other aspects, language can be consciously presented to one's partners in discursive interaction but also is less consciously revealed while pursuing other communicative and presentational goals; in other words, language is not only "given" but also "given off" (Goffman). Scholars viewing people as "active producers of their own identities" have also recognized that "linguistic resources form part of the repertoire of ways in which they bring their identities into being" (Tagg and Seargeant 164). Since the construction of identity in online interaction cannot rely on most of the non-verbal cues that play an important role in offline contexts, language becomes of particular importance. Studies of various social media practices examined how "participants constantly present different aspects of identity through careful choice of language according to their audience and the technological affordances of different platforms" (Lee, "Language," 94). The choice of language is complicated by the user's awareness of different likely audiences, which often include people about whose identities and preferences they know very little. Apart from a particular 
style of communication highlighting certain facets of the user's personality and implying a certain distance between the user and the primary audience (Page), the choice of language depends on the user's linguistic repertoire and the language he or she perceives to be appropriate in a given context. In the increasingly globalized world, participants in social media interactions often "perceive some distinction between a local, nationally defined community ... and other non-local groups which may not speak the participant's local language but with whom they use English as a lingua franca"; hence, their choice between a national and a more global language constructs their primary audience (Tagg and Seargeant 176). However, in many societies English or other transnational languages function in certain domestic practices so their use can be intended to indicate the user's relationship to such a practice and to other participants in that practice (Lee, "Micro-Blogging"; "Language").

Such is the case with the Russian language in post-Soviet Ukraine. On one hand Russian is the main language of transnational interaction between Ukrainians, Russians, and residents of other post-Soviet countries (as well as recent migrants from these countries), and on the other hand Russian is the preferred language of domestic use for many Ukrainians, particularly urbanites. Both of these roles manifest themselves in social media interactions, and it is not always clear which identity the use of Russian in a certain situation primarily indicates, because people seldom explicitly signal their orientation to a certain audience (Kulyk, "What Is"; "Negotiating"). In a post-imperial society characterized by common bilingualism and a large-scale discrepancy between ethnolinguistic identification and language practice, the very notions of Russian-speakers and Ukrainian-speakers are problematic. Not only do millions of Ukrainians use different languages in different practices or even in the same practice according to the audience, topic or other factors, but also millions of Ukrainians who primarily rely on Russian to communicate, actually identify with Ukrainian as their native language and support its spread in society and its promotion by the state (Kulyk, "The Age"; "Language Identity"). Moreover, while many Ukrainians use various mixtures of Ukrainian and Russian because of their inadequate proficiency in one or both of the languages, many educated people mix the two (or more) languages in the interest of creativity and self-expression. Social media communication provides a valuable forum for such self-expression, and people tend to resort to mixing languages more often in social media than elsewhere, thus further blurring the line between the Ukrainian- and Russian-speaking users (Bilaniuk, Contested; "Ideologies"). Nevertheless, the references to the supposedly clear-cut groups of speakers of Ukraine's two main languages are quite widespread in various discourses, including social media, which reflects the essentialist perception of ethnolinguistic processes on both 
mass and elite levels. While people who use mostly Russian in everyday life might not think of themselves as primarily Russian-speakers, ${ }^{3}$ people who use Ukrainian in everyday life are likely to perceive the use of Russian as a manifestation of Russian identity. Among other discourses, this difference can be noticed in social media interaction, as exemplified by the analysis below.

Methods used to study the construction of identities in various online contexts resulted from the view that this process can be accomplished "through a combination of associative patterns and communicative content" (Giplin 238). Hence, scholars paid attention to both particular networks of communication and discursive forms circulating therein. It is the latter component that is of particular relevance to my analysis of the of the self- and other-representations of "Russian-speakers" in Ukrainians' interaction on Facebook. Moreover, I am primarily interested in modes of identification defined by "membership in a class of persons sharing some categorical attribute" rather than by "position in a relational web" (Brubaker and Cooper 15). While earlier studies of self-categorization in social media focused on user profiles where "the range of resources for constructing the self is restricted by the platform designers' decisions about relevant information categories," later scholars came to pay more attention to "the user's own notions of what is relevant" as revealed in status updates (Vásquez 67). ${ }^{4}$ Most analyses of communicative content feature methods of discourse analysis adjusted to computer-mediated communication, and the analysis is often used in combination with some form of online ethnography (Hine; Herring; Androutsopoulos) such as interviews or focus groups with the target users and/or observation of these users' activities in social media (Lee, "Micro-Blogging"; Page). In view of the non-linear, multidirectional flow of social media interaction, it is hard to carve out a representative sample of discourse for detailed analysis, a problem scholars have tried to mitigate by focusing on particular

\footnotetext{
${ }^{3}$ In a 2014 survey, only 7 percent of respondents who claimed to use only or mostly Russian in everyday life chose "Russian-speakers" as one of three characteristics that best describe them, while 6 percent indicated "Russian." More popular were identifications as "man/woman" (48 percent), "Orthodox" (28 percent), "resident of my city/village" and, somewhat surprisingly, "Ukrainian" (27 percent each). Whatever the specific meaning of the latter designation for particular respondents, it is clear that the identification with the nation and/or country is more appealing to most Russian-speakers than the identification with their accustomed language of everyday use (Kulyk, "Identity").

4 Particularly in interactions between anonymous participants, profile identity claims "serve to provide additional context for readers' interpretation" of their unknown partners' statements, as Vásquez argues with regard to hotel reviews at a user-generated consumer site called TripAdvisor (77).
} 
discussion groups (KhosraviNik and Zia; Kozachenko) or particular users/pages (Zhao et al.; Kulyk, "Ukrainian"). Scholars who wish to examine various updates they see in their newsfeed face the problem of socalled filter bubbles (Pariser), that is, the limitation of access to texts, and therefore to views, that results from the user's settings and preferences in using the network in question. Since what one can see in one's newsfeed depends on one's choice of friends, pages to follow, groups to belong to, and, most importantly, network(s) to participate in, the detected trends can by no means be viewed as characteristic of network communication beyond this bubble. At the same time, newsfeed can be used to explore the context and select a sample for a more systematic discourse and ethnographic analysis; this is how it was done for earlier forms of the "new" media (Androutsopoulos).

\section{DATA}

My analysis of the representations of Ukraine's Russian-speakers in social media communication draws on a systematic examination of Facebook posts by twelve prominent Ukrainian users (hereafter described as "the sample"; see the list in the Appendix) for the entire year of 2016.5 These users (or rather accounts) were selected based on my long-term observation of Facebook interactions visible on my newsfeed. Apart from posts by my friends, I was able to see many other posts (by their friends or friends of friends), toward which they signalled their attitudes in the form of "likes," reposts, or comments. My Ukrainian friends are mostly people like myself-intellectuals, urbanites, and Ukrainian-speakers-but perhaps the main characteristics that they have in common are support for Ukraine's Western orientation, participation in or sympathy with Euromaidan, and unequivocal condemnation of Russia's military intervention in Ukraine. It is the views of this pro-Western and pro-Maidan segment of Ukraine's population in general and Facebook users in particular that the twelve selected users express and influence. Given the social prominence of individuals in the sample as writers, journalists, or public activists, their writing ability and social media productivity, their Facebook posts attracted great attention and often caused a considerable amount of commentary and even controversy. While hardly representative of the pro-Maidan segment in view of their social and intellectual standing, individuals in the sample possessed both the professional ability to grasp

${ }^{5}$ I considered only posts that included original text by the examined users but not those merely reposting material that had appeared elsewhere (however, reposts were included if accompanied by a comment). 
and articulate the mood of larger masses and the communication channels to shape it, not least by their regular posts on Facebook where they have dozens of thousands of registered friends and followers. ${ }^{6}$

Apart from their prominence and productivity, the sample selection took into account the Facebook users' occupation (more accurately, a social role that primarily contributes to their popularity), place of origin/residence, and main language used in Facebook posts in the year under examination (which did not necessarily coincide with the users' everyday communication). In line with the general profile of prominent Ukrainian users of Facebook, ten of the twelve selected Facebook users were male and eight currently had a permanent residence in Kyiv, although most individuals in the sample travelled extensively within Ukraine and beyond. The sample was evenly divided between media professionals, writers/artists, and activists helping to meet the demands of the Ukrainian military on the frontline (in today's Ukraine, such people are called "volontery," literally volunteers). Six posted mainly in Russian and six posted mainly in Ukrainian as of January 2016, although two switched from Russian to Ukrainian in the course of that year, a process that reflected the post-Maidan dynamics in Ukrainian society and particularly in Facebook interaction. Such an even linguistic distribution in the sample facilitated the analysis of both self- and other-representations of (people perceived as) Russian-speakers as well as enhanced the spectrum of interests and positions regarding language matters in Ukraine. As mentioned above, however, in post-imperial Ukraine, the preferred Facebook posting language does not necessarily coincide with the language that this individual primarily identifies with, or the language that he or she would apply in political and discursive confrontations. Indeed, the language used in Facebook does not always coincide with the language primarily used in everyday life. Many people use both Ukrainian and Russian for social media interaction; the more educated and/or globalized individuals frequently add other languages, particularly English, and many mix two or more languages, either because of poor knowledge of one or both of the languages or for creative purposes (Kulyk, "Language Identity"; "Negotiating"; Bilaniuk, "Ideologies"). While examining the language

\footnotetext{
${ }^{6}$ In September 2017, at the time of my systematic reading of the 2016 posts, the accounts under consideration had between 10,000 and 75,000 followers, in addition to just below the 5,000 limit of friends set by the Facebook administration. To be sure, the numbers could be considerably lower when those posts were written and actively read. It should be kept in mind, however, that in addition to the users' own friends and followers, their posts could normally be seen by friends and followers of those friends and followers who responded to the posts, which considerably increased the number of potential readers.
} 
distribution in the selected accounts as part of the context, my analysis focused on posts in which Ukrainian, Russian, or some combination of Ukrainian and Russian was employed.

The Facebook posts in the sample constructed, either categorically or relationally, many different identities of the authors, the people they wrote about, and the target audiences. Perhaps most obviously, individuals in the sample regularly informed readers about their most recent professional accomplishments (publications, performances, awards, business trips, etc.), thereby portraying themselves as professionally successful personalities and their Facebook readers as their fans, consumers of their work, and/or beneficiaries of their accomplishments. In addition, posted texts (often accompanied by pictures or videos) routinely presented the authors as loving parents, spouses, friends, enthusiastic travellers, sport and music fans, lovers of food and good company-roles with which most readers are expected to identify. Not surprisingly for the socially active personalities, their identities as (responsible) Ukrainian citizens were featured in many posts, often contrasting them either with citizens of other states, particularly Russians, or with Ukrainian politicians and bureaucrats who do not treat citizens with due respect. Readers of the sample posts were addressed as fellow citizens who were explicitly or implicitly encouraged to take a similar stance. While clear distancing from Russia and Russians was common to all analyzed posters, given their pro-Maidan personalities, their attitudes toward their own government ranged from tacit support to resolute opposition. Ideologically, all individuals in the sample manifested some mixture of broadly defined nationalism and liberalism, albeit with greatly varying ratios.

Linguistic identity seemed to be very salient for some and all but negligible for other individuals in the sample. While the former often discussed or otherwise clearly designated their linguistic identity and that of people they contrasted themselves with, the identity of the latter had to be "read off" from subtle discursive features. Accordingly, my analysis deals not only with posts that emphasize the belonging of the author or other people to a certain language group but also posts that indicate such belonging in the background. The analysis focuses on main topics, key arguments, and notable words used to make them. I begin with Facebook users in the sample who primarily relied on the Russian language and proceed to users who usually wrote in Ukrainian, keeping in mind that the language of Facebook communication, even if consistently used, does not necessarily amount to the poster's identification as a Russian-speaker. 


\section{A) Self-Representations: Practice And IDEntity}

As explained above, the mere fact of writing a post in Russian cannot be considered a manifestation of Russian-speaking identity. Actually, it cannot even serve as a reliable indicator of the author's predominant reliance on Russian in everyday life, as many people use Russian (or any other language) only occasionally, for particular purposes. However, an examination of a user's Facebook activities over a period of time makes it clear whether the choice of language in a particular post was an incident or an established practice. At the same time, even consistent use of the Russian language in Facebook posts does not necessarily indicate a strong identification with it; many of those who write exclusively or predominantly in Russian declare at some point that they identify with Ukrainian as their native and/or national language and some do not declare any linguistic identification at all. Most of these people see no need to relate language choice to their identity, background, language proficiency, or any other potentially relevant characteristic, thus manifesting their perception of this choice as perfectly normal, a perception also characteristic of most practices of the "old" media (Kulyk, Dyskurs, chap. 7; "Ideologies"). Moreover, most readers seem to share this perception as demonstrated by the scarcity of comments problematizing the posters' use of Russian, although such problematization became more frequent since the Russian invasion in 2014, which led many people to pay more attention to the relation between identity and language (Kulyk, "Language and Identity"). Therefore, the great majority of posts by people whose language practice seems to warrant their designation as Russian-speakers is treated here as merely a background to those relatively few texts where this practice is asserted, problematized or otherwise highlighted.

There are two main situations in which Ukrainian Facebook users highlighte a preference for Russian: (1) when announcing that they are (or will soon be) abandoning Russian and switching to Ukrainian and (2) when explaining why they are not going to abandon Russian and switch to Ukrainian, notwithstanding their opponents' critique. In case 1, the user proclaims a reliance on Russian first and foremost as an understandable fact of his or her biography. Dmytro Bulatov, a former Maidan activist and at the time of posting a Ukrainian army soldier on the frontline in the Donbas, $^{7}$ explained (3 January 2016) only his intended transition to Ukrainian but not his prior reliance on Russian. In contrast, volonter Rodion Shovkoshytnyi presented his accustomed speaking and thinking in Russian as not merely an established practice but a deeply rooted identity that he

7 Apart from the most salient social role, my presentation of the users includes those characteristics that are relevant for interpretation of their analyzed posts. 
had not perceived, for many years, as incompatible with his identity as a Ukrainian:

As long as I remember myself, I have always spoken Russian. This has always been the case. In this language, I have always rooted [for Ukrainian sport clubs and national teams] against Russian clubs and teams. In this language, I have supported our own [people], Ukraine and [everything] Ukrainian.

In this language, it is natural for me to express my thought and emotions (20 February 2016, in Russian). ${ }^{8}$

Similar to many other Ukrainian Russian-speakers, Bulatov and Shovkoshytnyi came to view their established language preference as inappropriate and made a determined effort to switch to Ukrainian, at least on Facebook. While obviously influenced by the ongoing Russian aggression, their final decision to start writing in Ukrainian was prompted by interactions with family, friends, and partners on social media. Shovkoshytnyi admitted an important role of Facebook discussions on the language issue, in particular, flash mobs of people switching to Ukrainian and offensive comments directed at himself and others who continued to write in Russian. This pressure eventually made him "leave the comfort zone" of relying on the accustomed language and enter the new terrain of using a language that he considered appropriate but had not yet fully mastered (20 February 2016, in Russian). For Bulatov, such a step was a response to the linguistic conversion of his fifteen-year-old son whose "emanation of patriotism" affected the father, compelling him to "correspond" to his son's idea of appropriate behaviour (3 January 2016, in Russian). In one of Bulatov's later posts, he articulated this (by then already internalized) idea as that of correspondence between national identity and language practice: "We are Ukrainians and must master our native language better than any other, regardless of earlier circumstances of personal life of each of us" (2 May 2016, in Ukrainian). This is one of numerous manifestations of a language ideology that I call the ideology of identification, which prioritizes the role of language as a marker of group identity, first and foremost a national one (Kulyk, "Ideologies").

\footnotetext{
8 All translations are mine. All of the posts referred to in this article were designated as public, meaning that the authors did not object to their circulation beyond the closed circle of their friends, resulting in numerous reposts by followers and friends of friends and other people who ran across their posts. In fact, the selected users often explicitly encouraged their readers to widely share a particular post. For this reason, these posts are cited on the same grounds as any other publicly circulating texts.
} 
In this and similar cases, the transition to Ukrainian on Facebook did not necessarily mean its predominant use in everyday life, which would require more effort and could expose the users to greater discomfort. Bulatov was making only first steps toward a reliance on Ukrainian as demonstrated by his numerous mistakes (of which he was aware and asked his readers to correct) and frequent reversion to Russian in particular posts. Shovkoshytnyi, after the announced transition, posted almost exclusively in Ukrainian but admitted that he still could not fully switch to this language in his private communication. At the same time, not only did the Facebook language transition presumably increase the respective poster's proficiency in Ukrainian and thus facilitate his or her reliance on it in other domains, it was likely to affect other Russian-speaking users by presenting Ukrainian as the (only) appropriate language of Facebook communication and, by extension, linguistic behaviour in Ukrainian society. While not explicitly denouncing Ukrainians who posted in Russian, Shovkoshytnyi's message implicitly delegitimized their language preference. This tolerant but critical attitude was obvious in one of Shovkoshytnyi's posts where he told a story of bringing his Ukrainianspeaking son to a football class in Kyiv and finding that everyone else was speaking Russian. Although he understood that the current predominance of Russian was "a result of many years of Russification work by a neighbouring territorial formation,"9 Shovkoshytnyi regretted that Ukrainian was "not becoming fashionable among the youth," that is, that other people did not speak the language themselves and did not help their children to embrace it (7 May 2016, in Ukrainian). Despite Shovkoshytnyi's occasional use of Russian, he came to identify unequivocally with Ukrainian, so his perspective on Russian-speakers changed from internal to external.

More often, however, Russian-speaking users perceive their language preference as fully legitimate. This perception is usually reflected in the lack of any problematization or justification of language choice, which is also true of posts and comments in Ukrainian. In contrast to Ukrainian, however, the use of Russian is sometimes criticized by commentators or disseminators of messages, thus urging the authors to explain their position. Such criticism is most likely in cases where some readers find the language of the post or comment at odds either with its substance, as when a call for wider use of and stronger support for Ukrainian is uttered in Russian, or with the personality of the author, as when Russian is used by a public servant who the reader expects to rely on Ukrainian. In the former case, critics usually do not admit that the user could specifically address

\footnotetext{
${ }^{9}$ Note that this formula presents the Soviet rule in Ukraine as an occupation by Russia.
} 
those people primarily using Russian so that the call would be perceived as made from within the group. In the latter, they seem to overlook or disregard an important difference between an official domain where the state language is indeed mandatory and public servants' interaction outside of that domain where they are free to use whatever language they like, even if they may be expected to manifest their support for the state/national language. In any event, harsh criticism of particular Russianspeakers often looks like delegitimization of the entire group (see below).

In responding to such critical statements, many Russian-speakers justify their own and other group members' adherence to the established practice by referring to the freedom of language choice in a democratic society and the important role of Russian-speakers in the Maidan democratic uprising and the subsequent defence of Ukraine. They challenge not only the supposed relation between language preference and the degree of patriotism but also the much more naturalized correspondence between a nation and its eponymous language which locates the Russian language outside of Ukraine, making it "the occupier's language." The Mariupol activist Iaroslav Matiushyn highlighted the inadequacy of this concept by presenting a radically different alternative, which emphasizes the use of Russian by many people defending Ukraine against the occupiers: "I consider it [the Russian language] the defender's language. I knew four [people] who will never again address anybody in the defender's language," a formulation implying that they died on the frontline (Matiushyn; in Russian, italicized parts in Ukrainian). ${ }^{10}$ Accordingly, Matiushyn denounced people who raised the issue of a supposedly inappropriate use of the Russian language as Moscow's agents who sought to undermine Ukraine's unity. At the same time, he argued that "we Russian-speaking patriots stand up for total Ukrainianization" but it should take the form of Ukrainian-language classes rather than antagonizing posts in social media (Matiushyn; in Russian). Some other popular Russianspeaking users also admitted that efforts should be made by both the state and active citizens to enhance the use of Ukrainian in various domains, while stressing that personal attacks on people using Russian in social media and everyday life undermine such efforts. While recognizing the value of the Ukrainian language as a marker of national identity, they were reluctant to sacrifice their freedom of choice and, one might assume, their "comfort zone."

However, far from all the Russian-speakers were so understanding and accommodating. Many simply insisted on their right to use the language

10 Although not part of the post itself, these words come from Matiushyn's text he shared in this post, so I decided to include it in my corpus, assuming that most readers of the post proceeded to the shared text. 
they were most comfortable with and did not discuss social factors affecting their choice or societal consequences of the widespread adherence to the post-imperial status quo, including the continued marginalization of the national language (Bilaniuk, "Ideologies"; Kulyk, "Language and Identity"). In my Facebook sample, the Odesa-born Jewish artist Oleksandr Roitburd, when criticized by a commentator, explained his predominant reliance on Russian in the following statement:

I speak Russian not because I do not speak Ukrainian. I speak Russian and Ukrainian. But I speak Russian better and Ukrainian less well. Therefore, I speak Russian. I consider Russian also a Ukrainian language. And not only I. At the same time, I sincerely sympathize with the revival of Ukrainian. You should stop wasting time on non-existing problems (cited in a post of 18 June 2016, in Russian).

Roitburd's statement embodies what I designate as the ideology of understanding, a widespread belief seeing language primarily not as a marker of group identity but as a conduit for conveying information (Kulyk, "Ideologies"). Having dismissed such critical commentators as "unicellular," meaning primitive, Roitburd in his later posts mentioned Facebook discussions on language use only ironically, making fun of those who took them seriously. At the same time, he was very serious about opposing the post-Maidan government's memory policy, which he believed was leading to "such a model of Ukraine that would be unacceptable to Jews and other non-titulars, including Russian-speaking Ukrainians" (Roitburd, 8 July 2016, in Russian). His consistent criticism of the government's effort to remove the communist era names and monuments in Kyiv and other cities revealed his concern about the loss of imperial culture for which the national one was allegedly unable to adequately substitute. While declaring their support for a Ukrainian linguo-cultural revival, he and many other Ukrainian Russian-speakers did not want this process to infringe on their accustomed linguistic landscape and cultural practices. Judging by their behaviour on Facebook and beyond, the Ukrainianization they were ready to support was by no means total.

B) Other-Representations: Between Ukrainian Patriotism And the "RUSSIAN WORLD"

The Facebook users who primarily rely on the Ukrainian language vary in their attitudes toward the prevalence of Russian in many Ukrainian social domains and the role of Russian-speakers in this situation. In my sample of prominent pro-Maidan personalities, manifestations of ethnocultural attitudes were rather reserved, possibly because they realized that hateful 
or simply insensitive statements might have a divisive effect on society, yet the authors differed radically in their attention to the language problem and their assessments thereof.

Not surprisingly, people who professionally deal with language and culture write about them more than those whose main preoccupation lies elsewhere. Roman Sinitsyn, one of the few Ukrainian-speakers among the well-known volontery, did not write about language matters at all in the year under examination, except a few times when he expressed his opinion about their political ramifications. For example, he commented very harshly on a news report about Russian journalist Matvei Ganapol'skii's intention to stop working for Ukrainian media if the so-called language quota-that is, requirements of a minimal share of air time in the state language-was introduced (2 November 2016, in a mixture of Ukrainian and Russian). This comment implied Sinitsyn's support for the quota and for the state promotion of the Ukrainian language more generally, even though his criticism focused not on the journalist's opposition to the quota but rather on his allegedly inappropriate activities in Ukraine. The Lvivborn media expert Ievhen Hlibovyts'kyi called on the pro-Maidan Russianlanguage magazine Novoe vremia (New Time) to launch a full-fledged version in Ukrainian. He argued that "the penetration of quality Ukrainianlanguage products into the Russian-speaking milieu in Ukraine has increased considerably for the last decade" (Hlibovyts'kyi, 2 June 2016, in Ukrainian), a formulation that presented Russian-speakers as mostly willing to consume media products in the titular language and, by extension, use it in other domains. Rather than lamenting the marginalization of Ukrainian in the media or elsewhere, he discussed ways to overcome it and assumed that Russian-speakers would contribute to achieving this noble goal. At the same time, Hlibovyts'kyi warned his fellow Galicians against excessive reliance in public discourse on their regional version of Ukrainian, which he believed could alienate the predominantly Russian-speaking residents in eastern Ukraine and thus undermine the promotion of the Ukrainian language (16 October 2016, in Ukrainian). This is a manifestation of the close relation between people's beliefs about language status and language corpus, that is, about appropriate social functions of a certain language variety and its appropriate forms (Kulyk, "Beliefs").

In contrast, some other Ukrainian-speaking users in my sample not only focused heavily on the promotion of the national language but also denounced the continued predominance of the former imperial language, thus signaling their adherence to the ideology of identification. For Oksana Zabuzhko, one of the best-known contemporary Ukrainian writers, the predominance of the Russian imperial language constitutes an "informational (including cultural) OCCUPATION," as most of the mass 
culture products are imported from Russia, while the Ukrainian culture has been reduced to small elite-oriented niches by allegedly intentional policies (27 February 2016, in Ukrainian, emphasis in the original). By implication, Ukraine's Russian-speakers do not produce any significant cultural artefacts and mostly consume products from across the border. However, many of them are supposedly willing to read "native" books such as Zabuzhko's own bestselling novel of the mid-1990s, a phenomenon she explained by post-independence changes in Ukrainians' political and cultural identity (29 February 2016, in Ukrainian). Accordingly, Zabuzhko called on her readers to sign a petition to the Ukrainian government to ban any import of audio and video products from Russia (28 March 2016, in Ukrainian). Moreover, she denounced Russian media professionals who have come to Ukraine to work as "little air men" ("efirnykh chelovechkov"), a media analogue of the "little green men" as unmarked Russian soldiers came to be known during Moscow's seizure of Crimea in March 2014. Zabuzhko alleged that such "little air men" were intended to implement the Kremlin's postulate of cultural commonality of the Russian and Ukrainian peoples. As for Ukrainian journalists working in Russian-language media, Zabuzhko saw them as merely paving the way for journalists from Russia (25 July 2016, in Ukrainian, quoted words in Ukrainian transliteration from Russian). In a similar vein, ethnic Russians who settled in Ukraine after the decimation of the indigenous population in the Holodomor of the early 1930s appear in Zabuzhko's narrative as paving the way for Russian tanks that invaded Ukraine in 2014 (26 November 2016, in Ukrainian). Her view is thus very different from those of people like Matiushyn or Hlibovyts'kyi, for whom these people and their descendants constitute an integral part of the Ukrainian nation.

The Uzhhorod-based writer Andrii Liubka and the television anchor from Lviv Ostap Drozdov were even more persistent in expressing indignation at the plight of their beloved Ukrainian language and criticism of those who did not want to help it. Liubka spoke of the sheer absurdity of the situation when even in predominantly Ukrainian-speaking cities in western Ukraine people often have to rely on Russian, which continues to dominate in certain practices such as taxi dispatchers' communication with customers. He called upon Ukrainian-speakers to refuse to accept Russian as the default language both in the service industry and in informal communication with Ukrainian Russian-speakers who, he believed, should be at least equally accommodative. While Russian-speakers who are willing to learn the Ukrainian language would supposedly welcome an opportunity to practice, a person who refused to even understand the Ukrainian language was, according to Liubka, "either a boor . . o or a sick person," in either case not worthy of an accommodating effort (28 August 2016, in Ukrainian). Drozdov attacked the organizers of a Lviv concert of a famous 
Ukrainian-language singer who were insensitive enough to force his fans to listen to warm-up songs in Russian, which Drozdov did not hesitate to call "the occupier's language," a designation in line with the general confrontational tone of his post (2 January 2016, in Ukrainian).

Fully convinced that the language problem in Ukraine constituted first and foremost marginalization of the titular language in many regions and social domains, Liubka and Drozdov vehemently denounced Russianspeakers who refused to share this conviction and support the resolute language policy it called for. In such denunciations the image of Russianspeaking Ukrainians became the exact opposite of the patriotic defenders of their homeland against Russian aggressors pictured by Matiushyn and many other users predominantly writing in Russian. Since many Facebook posts did not clearly distinguish between particular individuals and the entire Russian-speaking part of society, the allegedly unacceptable words and deeds of the former were inevitably projected onto the latter. In his post supporting the Ukrainian government's measures to limit book import from Russia, Liubka scornfully asserted that those who "started to howl" about pernicious consequences of such measures were people "whose patriotism is aimed at building in Ukraine not a Ukraine but a democratic, normal, European Russia" (21 February 2016, in Ukrainian). In this description, the dream of Ukraine as a (better) version of Russia was primarily attributed to a relatively small group of active opponents of Ukrainianization. In contrast, Drozdov in one of his posts went as far as to blame the entire Russian-speaking "half of Ukraine" as seeking revenge after the victory of the Euromaidan revolution which he saw as aimed at Ukraine's emancipation from Russia:

This omnivorous half now, in the second year after the Revolution, takes the initiative. Playing in their headphones are [the Russian pop singers] Leps and Shufutinskii, their children are raised on fairy tales by Pushkin, their native language is the language of [the Moscow Patriarch] Cyril, their church is the Moscow Patriarchy [rather than the Kyiv Patriarchy], their party is the Opposition block [the rebranded party of former collaborators of Ianukovych], their native memory is the Day of Victory over fascists [which has become in Ukraine a symbol of the pro-Russian orientation]. (29 February 2016, in Ukrainian)

By portraying virtually all Russian-speakers as tied to Russia and hostile to Euromaidan, this representation denied them not merely genuine Ukrainian patriotism but even legitimacy as equal members of Ukrainian society, thereby clearly locating them outside of the Ukrainian national "self" and, by the same token, effectively reducing the nation to speakers of its titular language. Paradoxically, such representations suggested that Ukraine's Russian-speakers were an inherent part of the Moscow-centred 
cultural and political realm known as the "Russian world," just as in representations of those who launched a war to save these people from "forcible Ukrainianization" in the wake of the allegedly Western-sponsored Euromaidan.

\section{CONCLUSION}

As the above analysis has demonstrated, Facebook contributions of prominent representatives of the pro-Maidan segment of Ukrainian society constructed a contradictory image of Russian-speakers as both part of Ukraine's national "self" and its internal "other." By emphasizing the "otherness" of Putin's Russia and downplaying their personal choice in favour of the Russian language, Ukrainians posting in Russian in social media tended to present themselves as an integral part of Ukrainian society, that is, as Ukrainian patriots who happen to speak mostly Russian. While not explicitly excluding them, many of their predominantly Ukrainian-speaking compatriots highlighted the importance of the national language for the nation's survival and development, thus urging individuals speaking Russian to convert or else face exclusion. Some eagerly or grudgingly complied, at least on Facebook, but others insisted on their right to use their accustomed language, a stand that ardent supporters of the Ukrainian language denounced as insensitive at best and treacherous at worst. For the latter, it is the language that defines people who continue speaking Russian, hence it appears as a crucial element of their social identity rather than merely a facet of communicative practice. By ascribing to their Russian-speaking compatriots a salient identity distinct from the Ukrainian one, their critics manifested their perception of Ukrainianness as closely related to the eponymous language, while those insisting on their right to use whatever language they prefer perceived the Ukrainian identity to be defined by individual choice and civic loyalty. Other Facebook posters studied here insisted on their right to use whatever language they prefer and perceived the Ukrainian identity to be defined by individual choice and civic loyalty. At the same time, online and offline discussions between those arguing that language matters greatly for Ukraine and those who believe it does not, manifest their different perceptions of the role of individual choice and social conditions in language use. Moreover, as the war politicized language choice, "more people are engaging in determining just how language matters, both in their personal choices and in activism to shape the choices of the rest of society" (Bilaniuk, "Ideologies," 157).

Although this study did not include a systematic analysis of comments under the studied Facebook posts, a cursory examination showed that commentators tend to agree with the position expressed by the post's 
author, which confirms a general tendency of social media users to engage with like-minded people and consonant messages and filter off those they strongly disagree with (Williams et al.; Duggan and Smith). However, similarly to social media discourse on the equally controversial topics of Ukrainian collective memory (Kulyk, "Negotiating"), some of the readers raised a dissenting voice, often provoking a heated discussion. Whether in agreement or disagreement, little-known or anonymous commentators often expressed more radical and hateful views than fully identifiable and socially constrained posters, such as the prominent personalities discussed in this article. At the same time, many more readers of the posts only signaled their attitudes by "likes" and probably still more did not signal attitudes at all. While analysis of social media discourse indicates participants' arguments, words, and underlying assumptions, ethnographic research is needed to assess the impact of these interactions on silent observers, including their identification of the discussants as belonging to certain ethnolinguistic and other relevant categories. Moreover, analyses of posts by popular and influential personalities should be supplemented by examination of writings by less prominent social media users, more representative of certain large groups of society.

\section{Works Cited}

Aguila, Almond Pilar Nable. "Social Media and the Renegotiation of Filipino Diasporic Identities.” Dissertation, University of Alberta, 2014.

Anderson, Benedict. Imagined Communities: Reflections on the Origin and Spread of Nationalism. Revised ed., Verso, 1991.

Androutsopoulos, Jannis. "Potentials and Limitations of Discourse-Centred Online Ethnography." Language@Internet, vol. 5, 2008, article 8, http://www.languageatinternet.org/articles/2008/1610. Accessed 18 Oct. 2017.

Bilaniuk, Laada. Contested Tongues: Language Politics and Cultural Correction in Ukraine. Cornell UP, 2005.

---. "Ideologies of Language in Wartime." Revolution and War in Contemporary Ukraine: The Challenge of Change, edited by Olga Bertelsen, Ibidem, 2016, pp. 139-60.

Billig, Michael. Banal Nationalism. Sage, 1995.

Bimber, Bruce, and Richard Davis. Campaigning Online: The Internet in U.S. Elections. Oxford UP, 2003.

Blommaert, Jan. Discourse: A Critical Introduction. Cambridge UP, 2005.

boyd, Danah, and Jeffrey Heer. "Profiles as Conversation: Networked Identity Performance on Friendster." Proceedings of the Hawai'i International Conference on System Sciences (HICSS-39), IEEE Computer Society, 4-7 Jan. 2006. DOI: 10.1109/HICSS.2006.394, 
http://ieeexplore.ieee.org/abstract/document/1579411/?reload=true.

Accessed 18 Aug. 2017.

Brubaker, Rogers, and Frederick Cooper. "Beyond 'Identity.'” Theory and Society, vol. 29, no. 1, 2000, pp. 1-47. DOI: 10.1023/A:1007068714468.

Castells, Manuel. Networks of Outrage and Hope: Social Movements in the Internet Age. John Wiley \& Sons, 2013.

Chan, Brenda. "Imagining the Homeland: The Internet and Diasporic Discourse of Nationalism." Journal of Communication Inquiry, vol. 29, no. 4, 2005, pp. 336-68. DOI: $10.1163 / 179325406788639093$.

Duggan, Maeve, and Aaron Smith. "The Political Environment on Social Media." Pew Research Center, 25 Oct. 2016, http://www.pewinternet.org/2016/10/25/thepolitical-environment-on-social-media/. Accessed 18 Aug. 2017.

Fairclough, Norman. Media Discourse. Edward Arnold, 1995.

Gauntlett, David. Media, Gender and Identity: An Introduction. 2nd ed., Routledge, 2008.

Giplin, Dawn R. "Working the Twittersphere: Microblogging as Professional Identity Construction." A Networked Self: Identity, Community, and Culture on Social Network Sites, edited by Zizi Paracharissi, Routledge, 2011, pp. 232-50.

Goffman, Erving. The Presentation of Self in Everyday Life. Doubleday, 1959.

Herring, Susan C. "Computer-Mediated Discourse Analysis: An Approach to Researching Online Behavior." Designing for Virtual Communities in the Service of Learning, edited by Sasha A. Barab et al., Cambridge UP, 2004, pp. 338-76.

Hill, Kevin A., and John E. Hughes. "Computer-Mediated Political Communication: The USENET and Political Communities." Political Communication, vol. 14, no. 1, 1997, pp. 3-27. DOI: 10.1080/105846097199515.

Hine, Christine. Virtual Ethnography. Sage, 2000.

Holt, Richard. Dialogue on the Internet: Language, Civic Identity, and ComputerMediated Communication. Praeger, 2004.

Ibañez, Jorge Larraín. "The Concept of Identity." National Identities and Sociopolitical Changes in Latin America, edited by Mercedes F. Durán-Cohan and Antonio Gómez-Moriana, Routledge, 2001, pp. 1-29.

Johnson, Thomas J., et al. "United We Stand? Online Social Network Sites and Civic Engagement." A Networked Self: Identity, Community, and Culture on Social Network Sites, edited by Zizi Paracharissi, Routledge, 2011, pp. 185-207.

KhosraviNik, Majid. "The Representation of Refugees, Asylum Seekers and Immigrants in British Newspapers during the Balkan Conflict (1999) and the British General Election (2005)." Discourse and Society, vol. 20, no. 4, 2009, pp. 477-98. DOI: 10.1177/0957926509104024.

---, and Mahrou Zia. "Persian Nationalism, Identity and Anti-Arab Sentiments in Iranian Facebook Discourses: Critical Discourse Analysis and Social Media Communication." Journal of Language and Politics, vol. 13, no. 4, 2014, pp. 75580. DOI: 10.1075/jlp.13.4.08kho.

Kozachenko, Ivan. "Retelling Old Stories with New Media: National Identity and Transnationalism in the 'Russian Spring' Popular Uprisings." East/West: Journal of Ukrainian Studies, vol. 4, no. 1, 2017, pp. 137-158. DOI: http://dx.doi.org/10.21226/T2B01T. 
Kulyk, Volodymyr. "The Age Factor in Language Practices and Attitudes: Continuity and Change in Ukraine's Bilingualism." Nationalities Papers, vol. 43, no. 2, 2015, pp. 283-301. DOI: 10.1080/00905992.2014.971725.

---. "Beliefs about Language Status and Corpus in Focus Group Discussions on the Ukrainian Language Policy." International Journal of the Sociology of Language, no. 212, 2011, pp. 69-89. DOI: 10.1515/ijsl.2011.047.

---. Dyskurs ukrains'kykh medii: Identychnosti, ideolohii, vladni stosunky. Krytyka, 2010.

---. "Identity in Transformation: Russian-Speakers in Post-Soviet Ukraine." EuropeAsia Studies, 14 Dec. 2017, DOI: 10.1080/09668136.2017.1379054.

---. "Ideologies of Language Use in Post-Soviet Ukrainian Media." International Journal of the Sociology of Language, no. 201, 2010, pp. 79-104. DOI: 10.1515/IJSL.2010.005.

---. "Language Identity, Linguistic Diversity and Political Cleavages: Evidence from Ukraine." Nations and Nationalism, vol. 17, no. 3, 2011, pp. 627-48. DOI: 10.1111/j.1469-8129.2011.00493.x.

---. "Language and Identity in Ukraine after Euromaidan." Thesis Eleven, vol. 136, no. 1, 2016, pp. 90-106. DOI: 10.1177/0725513616668621.

---. "Negotiating Memory in Online Social Networks: Ukrainian and UkrainianRussian Discussions of Soviet Rule and Anti-Soviet Resistance." Disputed Memory: Emotions and Memory Politics in Central, Eastern and South-Eastern Europe, edited by Tea Sindbæk Andersen and Barbara Törnquist-Plewa, De Gruyter, 2016, pp. 273-96.

---. "Ukrainian Nationalism since the Outbreak of Euromaidan." Ab Imperio, no. 3, 2014, pp. 94-122. DOI: 10.1353/imp.2014.0064.

---. "What Is Russian in Ukraine? Popular Beliefs Regarding the Social Roles of the Language." The Russian Language Outside the Nation: Speakers and Identities, edited by Lara Ryazanova-Clarke, Edinburgh UP, 2014, pp. 117-40.

Kushin, Matthew J., and Kelin Kitchener. "Getting Political on Social Network Sites: Exploring Online Political Discourse on Facebook." First Monday, vol. 14, no. 11, 2009. DOI: $10.5210 /$ fm.v14i11.2645.

Lee, Carmen K. M. "Micro-Blogging and Status Updates on Facebook: Texts and Practices." Digital Discourse: Language in the New Media, edited by Crispin Thurlow and Kristine Mroczek, Oxford UP, 2011, pp. 110-28.

Lee, Carmen. "Language Choice and Self-Presentation in Social Media: The Case of University Students in Hong Kong." The Language of Social Media: Identity and Community on the Internet, edited by Philip Seargeant and Caroline Tagg, Palgrave Macmillan, 2014, pp. 91-111.

Matiushin (Matiushyn), Iaroslav. "Manifest russkoiazychnogo patriota." Site.ua, 18 Feb. 2016, https://site.ua/yaramatjushyn/2789-manifest-russkoyazychnogopatriota/. Accessed 18 Aug. 2017.

Morley, David. "Broadcasting and the Construction of the National Family." The Television Studies Reader, edited by Robert C. Allen and Annette Hill, Routledge, 2004, pp. 418-41.

Onuch, Olga. "EuroMaidan Protests in Ukraine: Social Media versus Social Networks." Problems of Post-Communism, vol. 62, no. 4, 2015, pp. 217-35. DOI: 10.1080/10758216.2015.1037676. 
Page, Ruth E. Stories and Social Media: Identities and Interaction. Routledge, 2012.

Pariser, Eli. The Filter Bubble: What the Internet Is Hiding from You. Penguin Press, 2011.

Parks, Malcolm R. “Social Network Sites as Virtual Communities.” A Networked Self: Identity, Community, and Culture on Social Network Sites, edited by Zizi Paracharissi, Routledge, 2011, pp. 105-23.

Siibak, Andra. "Constructing the Self through the Photo Selection-Visual Impression Management of Social Networking Websites." Cyberpsychology: Journal of Psychosocial Research on Cyberspace, vol. 3, no. 1, 2009, article 1, https://cyberpsychology.eu/article/view/4218/3260. Accessed 18 Aug. 2017.

Smith, Marc A., and Peter Kollock, editors. Communities in Cyberspace. Routledge, 1999.

Tagg, Caroline, and Philip Seargeant. "Audience Design and Language Choice in the Construction and Maintenance of Translocal Communities on Social Network Sites." The Language of Social Media: Identity and Community on the Internet, edited by Philip Seargeant and Caroline Tagg, Palgrave Macmillan, 2014, pp. 161-85.

Turkle, Sherry. Life on the Screen: Identity in the Age of the Internet. Simon \& Schuster, 1995.

van Djik, Teun A. "Mediating Racism. The Role of the Media in the Reproduction of Racism." Language, Power and Ideology. Studies in Political Discourse, edited by Ruth Wodak, John Benjamins Publishing, 1989, pp. 199-226.

Vásquez, Camilla. "Usually Not One to Complain but...': Constructing Identities in User-Generated Online Reviews." The Language of Social Media: Identity and Community on the Internet, edited by Philip Seargeant and Caroline Tagg, Palgrave Macmillan, 2014, pp. 65-90.

Williams, Hywel T. P., et al. "Network Analysis Reveals Open Forums and Echo Chambers in Social Media Discussions of Climate Change." Global Environmental Change, vol. 32, 2015, pp. 126-38. DOI: 10.1016/j.gloenvcha.2015.03.006.

Wodak, Ruth, et al. The Discursive Construction of National Identity. Edinburgh UP, 1999.

Zhao, Shanyang, et al. "Identity Construction on Facebook: Digital Empowerment in Anchored Relationships." Computers in Human Behavior, vol. 24, no. 5, 2008, pp. 1816-36. DOI: doi:10.1016/j.chb.2008.02.012. 


\section{Appendix}

The list of users whose accounts have been systematically analyzed

Bulatov, Dmytro; account name Dmitry Bulatov; in 2016, a soldier of the Ukrainian army stationed in the Donbas; writing initially in Russian, then increasingly in Ukrainian.

Drozdov, Ostap; account name Ostap Drozdov; a journalist and television anchor based in Lviv; writing in Ukrainian.

Hlibovyts'kyi, Ievhen; account name Євген Глібовицький (Yevhen Hlibovytsky); a media expert based in Kyiv and Lviv; writing predominantly in Ukrainian.

Hnap, Dmytro; account name Дмитро Гнап; a journalist based in Kyiv; writing mostly in Ukrainian, with frequent posts or fragments in Russian.

Koshkina, Sonia (real name Kseniia Vasylenko); account name Sonya Koshkina; a journalist and editor based in Kyiv; writing predominantly in Russian.

Kurkov, Andrii; account name Andrei Kurkov; a writer based in Kyiv; writing mostly in Russian, with frequent posts or fragments in Ukrainian.

Liubka, Andrii; account name Andriy Lyubka; a writer based in Uzhhorod; writing in Ukrainian.

Matiushyn, Iaroslav; account name Ярослав Матюшин; an activist (volonter) based in Mariupol; writing predominantly in Russian, sometimes with admixtures of Ukrainian.

Roitburd, Oleksandr; account name Олександр Ройтбурд; an artist based in Kyiv; writing predominantly in Russian.

Shovkoshytnyi, Rodion; account name Rodion Shovkoshytnyi; an activist (volonter) based in Kyiv; in 2016 initially writing in Russian, then switching to Ukrainian.

Sinitsyn, Roman (real name Roman Balan); account name Roman Sinicyn; an activist (volonter) based in Kyiv; writing predominantly in Ukrainian, frequently with admixtures of non-standard speech.

Zabuzhko, Oksana; account name Oksana Zabuzhko (Оксана Забужко); a writer based in Kyiv; writing in Ukrainian. 